Check for updates

Cite this: RSC Adv., 2017, 7, 46980

Received 25th August 2017

Accepted 22nd September 2017

DOI: $10.1039 / c 7 r a 09423 j$

rsc.li/rsc-advances

\section{Synthesis, crystal structure, photophysical property and metal ion-binding behavior of a cyclometalated platinum(II) terpyridylacetylide with efficient $\pi$-conjugation degree $\uparrow$}

\author{
Dongqin Bi, Yuquan Feng, Qian Zhao, Hongwei Wang, Yongsheng Zhu, (DD \\ Xiaoyu Bao, Huitao Fan, Lintao Yu, Qichao Yang and Dongfang Qiu (DD*
}

\begin{abstract}
A cyclometalated Pt(॥) acetylide derivative bearing a carbazole donor and a terpyridine (TPY) receptor has been successfully synthesized and characterized. X-ray crystallography shows its monoclinic crystal system with the $P 2(1) / c$ space group and the three-component co-planarity molecular structure. This efficient $\pi$-conjugation system displays an intense low-energy absorption band $(\varepsilon=1.51 \times$ $\left.10^{4} \mathrm{dm}^{3} \mathrm{~mol}^{-1} \mathrm{~cm}^{-1}\right)$ at $\lambda_{\max }=442 \mathrm{~nm}$ and a strong phosphorescence emission $(\Phi=0.045)$ at $\lambda_{\max }=$ $596 \mathrm{~nm}$ in an air-saturated $\mathrm{CH}_{2} \mathrm{Cl}_{2}$ solution at room temperature, resulting from the $\mathrm{d} \pi(\mathrm{Pt}) \rightarrow$ $\pi^{*}\left(\mathrm{C}^{\wedge} \mathrm{N}^{\wedge} \mathrm{N}\right)$ metal-to-ligand charge transfer (MLCT) mixing with the $\pi(\mathrm{C} \equiv \mathrm{C}-\mathrm{Ar}) \rightarrow \pi^{*}\left(\mathrm{C}^{\wedge} \mathrm{N} \wedge \mathrm{N}\right)$ ligandto-ligand charge transfer (LLCT) transition. With the introduction of the TPY receptor, this complex possesses ca. 1.6-fold luminescence-enhancing response for $\mathrm{Zn}^{2+}$ and $\mathrm{Cd}^{2+}$ but dramatic luminescence quenching response toward other common transition metal cations. Consecutive titrations exhibit that the added metal ions bond to its free TPY receptor with $1: 2$ stoichiometry to form the heterotrinuclear (Pt-M-Pt) complex. The Fe ${ }^{2+}$-quenched and $\mathrm{Zn}^{2+}$-enhanced luminescence behaviors with the maximum PET efficiency of $92.4 \%$ and $62.7 \%$, respectively, strongly suggest the presence of the intra-molecular energy transfer between the $\left[\mathrm{M}(\mathrm{TPY})_{2}\right]^{2+}$ core and the terminal phosphorescent $\mathrm{Pt}\left({ }^{\prime \prime}\right)$ complex units.
\end{abstract}

\section{Introduction}

Luminescent chemosensors with high sensitivity and selectivity have been widely studied for their attractive potential in environmental and bio-medical applications. ${ }^{\mathbf{1 , 2}}$ The "Chromophore-Spacer-Receptor" model has been generally designed, and the transition metal complexes with electronic transition in visible/near-IR region, high quantum efficiency and long lifetime have been extensively employed as fluorophores instead of the organic counterparts. ${ }^{3}$ Owing to their intriguing spectroscopic and luminescence properties, square-planar platinum(II) polypyridyl complexes imparted with metal-binding units, such as P- and N-donor crown ether pendants, ${ }^{4} \mathrm{~S}$-benzo-15-crown-5, ${ }^{5}$ 4-ethynylbenzo-15-crown-5, ${ }^{6} \quad$ 5,17-diethynyl-25,27-dimethoxycalix $[4]$ crown $-5,{ }^{7}$ bipyridylacetylides,${ }^{8}$ and terpyridylacetylides, ${ }^{9}$ have been reported in such investigations. Since the strong

College of Chemistry and Pharmacy Engineering, Nanyang Normal University, Nanyang, 473061, P. R. China. E-mail: qiudf2008@163.com; Fax: +86-37763513595; Tel: +86-377-63513595

$\dagger$ Electronic supplementary information (ESI) available: Crystal data, luminescence intensity decay, UV-vis absorption and PL spectra, and the Stern-Volmer and Benesi-Hildebrand plots. CCDC 991876 and 991877 . For ESI and crystallographic data in CIF or other electronic format see DOI: 10.1039/c7ra09423j ligand field effect of the cyclometalated carbon raises the energy of the $\mathrm{d}-\mathrm{d}$ states to reduce the non-radiation decay probability, cyclometalated platinum(II) complexes with tridentate phenylsubstituted pyridine $\left[\left(\mathrm{N}^{\wedge} \mathrm{C}^{\wedge} \mathrm{N}\right) \text { motif }\right]^{\mathbf{1 0 - 1 6}}$ and bipyridine $\left[\left(\mathrm{C}^{\wedge} \mathrm{N}^{\wedge} \mathrm{N}\right) \text { motif }\right]^{17-22}$ as well as the related diphenyl-substituted pyridine $\left[\left(\mathrm{C}^{\wedge} \mathrm{N}^{\wedge} \mathrm{C}\right) \text { motif }\right]^{23,24}$ ligands are good emitters with high quantum yields at room temperature, which are expected to be used as better candidates in chemosensors. ${ }^{25,26}$ Cyclometalated $\left[\left(\mathrm{C}^{\wedge} \mathrm{N}^{\wedge} \mathrm{N}\right) \mathrm{Pt}(\mathrm{II})\right] \sigma$-alkynyl complex with a benzo-15azacrown-5 receptor ${ }^{27}$ and a bis(2-picolyl)aniline (DPA) receptor ${ }^{28}$ have been applied in ion-binding studies. Our group reported a cyclometalated $\left[\left(\mathrm{C}^{\wedge} \mathrm{N}^{\wedge} \mathrm{N}\right) \mathrm{Pt}(\mathrm{II})\right]$ terpyridylacetylide with a rich electron-donating bis-arylamine moiety, which exhibits the $\mathrm{H}^{+}$-triggered, $\mathrm{Zn}^{2+}$-enhanced and $\mathrm{OH}^{-}$-quenched phosphorescence properties and an unexpected $\mathrm{Zn}^{2+}$-selective luminescence chemosensor behavior in acid solution. ${ }^{29}$ However, owing to the lack of a clear molecular structure, the structure-property relationship is not well established for this class of multi-component compounds.

Herein, we design a novel three-component molecular system (Chart 1, complex 3), in which the $\left[\left(\mathrm{C}^{\wedge} \mathrm{N}^{\wedge} \mathrm{N}\right) \mathrm{Pt}(\mathrm{II})\right]$ acetylide core and the pendant TPY unit still serve as a planar fluorophore and a general receptor for transition metal ions, respectively, while the carbazole (CBZ) moiety serves as a rigid 


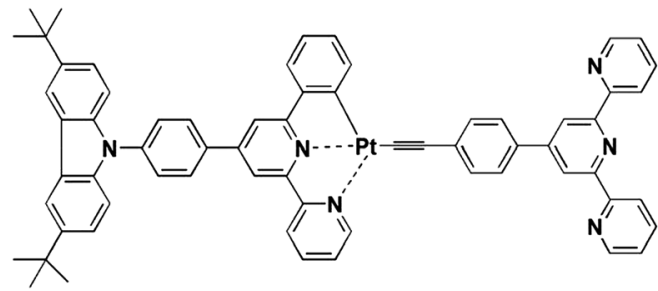

\section{3}

Chart 1 Molecular structure of complex 3

and higher energy-donating component. Its synthesis, crystal structure, photophysical properties, and transition metal ionbinding luminescence behaviors are mainly discussed with complex 2 (Scheme 1) as the reference compound.

\section{Experimental}

\section{Materials and general procedures}

The commercially available regents 3,6-di-tert-butylcarbazole, 18-crown-6, triethylamine $\left(\mathrm{Et}_{3} \mathrm{~N}\right)$, phenylacetylene $\left(\mathrm{C}_{6} \mathrm{H}_{5} \mathrm{C} \equiv \mathrm{CH}\right)$, anhydrous $\mathrm{K}_{2} \mathrm{CO}_{3}$, CuI, and $\mathrm{K}_{2} \mathrm{PtCl}_{4}$ were of analytical grade and used as received without further purification. Reactions were carried out under an argon atmosphere in an oven-dried glassware using standard Schlenk techniques. The solvents used for synthesis were also of analytical grade. Diisopropylamine was treated with $5 \AA$ molecular sieves and distilled under an argon atmosphere from molten sodium. Dichloromethane was distilled before using it as a solvent for photophysical and electrochemical determinations of the sample. All metal salts, such as $\mathrm{Zn}\left(\mathrm{ClO}_{4}\right)_{2}, \mathrm{Cd}\left(\mathrm{ClO}_{4}\right)_{2}, \mathrm{Fe}\left(\mathrm{ClO}_{4}\right)_{2}$, $\mathrm{NaClO}_{4}, \mathrm{KClO}_{4}, \mathrm{Ca}\left(\mathrm{CH}_{3} \mathrm{COO}\right)_{2}, \mathrm{Mg}\left(\mathrm{CH}_{3} \mathrm{COO}\right)_{2}, \mathrm{Mn}\left(\mathrm{CH}_{3} \mathrm{COO}\right)_{2}$, $\mathrm{Co}\left(\mathrm{CH}_{3} \mathrm{COO}\right)_{2}, \quad \mathrm{Ni}\left(\mathrm{CH}_{3} \mathrm{COO}\right)_{2}, \mathrm{Cu}\left(\mathrm{CH}_{3} \mathrm{COO}\right)_{2}$, and $\mathrm{Pb}\left(\mathrm{CH}_{3}^{-}\right.$ $\mathrm{COO})_{2}$, were of analytical reagent grade and used as supplied to prepare the titrant $\mathrm{CH}_{3} \mathrm{OH}$ solutions containing $3.5 \times$ $10^{-3} \mathrm{~mol} \mathrm{dm}^{-3}$ metal ions. Tetrabutylammonium perchlorate $\left({ }^{t} \mathrm{Bu}_{4} \mathrm{NClO}_{4}\right)$, the supporting electrolyte for electrochemical studies, was prepared by the metathesis of tetrabutylammonium bromide and perchloric acid. The electrolyte was recrystallized from hot pentanol/ethyl acetate solution twice to give colorless crystals and dried in a vacuum oven. (Caution: perchlorate salts are potentially explosive and should be handled with care and in small amounts.)

Syntheses of 4-( $p$-bromophenyl)-6-phenyl-2,2'-bipyridine and $4^{\prime}$-(4-ethynylphenyl)-2,2':6', $2^{\prime \prime}$-terpyridine have been described previously. ${ }^{29}$

\section{Synthesis of 4-\{p-[9-(3,6-di-tert-butyl)carbazolyl] $\}$-phenyl-6- phenyl-2, 2'-bipyridine (HL)}

A mixture of 3,6-di-tert-butylcarbazole (3.91 g, $14.0 \mathrm{mmol})$, 4-( $p$ bromophenyl)-6-phenyl-2,2'-bipyridine $(3.87 \mathrm{~g}, 10.0 \mathrm{mmol})$, anhydrous $\mathrm{K}_{2} \mathrm{CO}_{3}(4.18 \mathrm{~g}, 30.0 \mathrm{mmol})$, $\mathrm{CuI}(0.12 \mathrm{~g}, 0.6 \mathrm{mmol})$, and 18-crown-6 $(0.28 \mathrm{~g}, 1.1 \mathrm{mmol})$ was transferred into a flask, purged with argon, and then heated to $185^{\circ} \mathrm{C}$ under stirring for $24 \mathrm{~h}$. After the reaction mixture was cooled to ambient temperature, $\mathrm{CH}_{2} \mathrm{Cl}_{2}$ and $\mathrm{H}_{2} \mathrm{O}$ were added. The aqueous phase was discarded, and the organic phase was washed with distilled
$\mathrm{H}_{2} \mathrm{O}$ and then dried over anhydrous $\mathrm{Na}_{2} \mathrm{SO}_{4}$. The evaporated residue was applied to a chromatography column (neutral $\mathrm{Al}_{2} \mathrm{O}_{3}$ ) and eluted with $\mathrm{CH}_{2} \mathrm{Cl}_{2}$-petroleum ether $(2: 1)$. The pure product was obtained by recrystallization from its $\mathrm{MeOH} /$ $\mathrm{CH}_{2} \mathrm{Cl}_{2}$ solution as a white crystal in a yield of $78 \% .{ }^{1} \mathrm{H}$ NMR $\left(400 \mathrm{MHz}, \mathrm{CDCl}_{3}\right): \delta 8.76-8.73(\mathrm{~m}, 3 \mathrm{H}), 8.26(\mathrm{~d}, J=7.6 \mathrm{~Hz}, 2 \mathrm{H})$, $8.16(\mathrm{~s}, 2 \mathrm{H}), 8.09(\mathrm{~s}, 1 \mathrm{H}), 8.05(\mathrm{~d}, J=8.0 \mathrm{~Hz}, 2 \mathrm{H}), 7.90(\mathrm{t}, J=$ $7.6 \mathrm{~Hz}, 1 \mathrm{H}), 7.73(\mathrm{~d}, J=8.4 \mathrm{~Hz}, 2 \mathrm{H}), 7.56(\mathrm{t}, J=7.4 \mathrm{~Hz}, 2 \mathrm{H}), 7.51-$ $7.43(\mathrm{~m}, 5 \mathrm{H}), 7.38(\mathrm{t}, J=6.0 \mathrm{~Hz}, 1 \mathrm{H}, A r), 1.52\left(\mathrm{~s}, 18 \mathrm{H},-\mathrm{CH}_{3}\right) .{ }^{13} \mathrm{C}$ $\left\{{ }^{1} \mathrm{H}\right\}$ NMR $\left(100 \mathrm{MHz}, \mathrm{CDCl}_{3}\right): \delta 157.4,156.3,156.2,149.4,149.0$, 143.2, 139.4, 139.0, 138.9, 137.1, 137.0, 129.2, 128.8, 128.7, 127.1, 127.0, 124.0, 123.8, 123.6, 121.7, 118.4, 117.5, 116.4, 109.2 $(\mathrm{Ar}), 34.8\left(-\mathrm{C}\left(\mathrm{CH}_{3}\right)_{3}\right), 32.0\left(-\mathrm{CH}_{3}\right)$; elemental analysis calcd (\%) for $\mathrm{C}_{31} \mathrm{H}_{28} \mathrm{~N}_{4}$ : C, 81.55; H, 6.18; N, 12.27; found: $\mathrm{C}, 81.79 ; \mathrm{H}$, $6.20 ; \mathrm{N}, 11.98$.

\section{Synthesis of 1}

A mixture of $\mathrm{HL}(0.29 \mathrm{~g}, 0.5 \mathrm{mmol}), \mathrm{K}_{2} \mathrm{PtCl}_{4}(0.21 \mathrm{~g}, 0.5 \mathrm{mmol})$ and glacial acetic acid $(50 \mathrm{~mL})$ was refluxed for $12 \mathrm{~h}$ under an argon atmosphere in the absence of light. The reaction mixture was then cooled to room temperature and filtered. The obtained solid was recrystallized from $\mathrm{MeOH} / \mathrm{CH}_{2} \mathrm{Cl}_{2}$ solution to form the desired product as an orange crystal in a yield of $92 \% .{ }^{1} \mathrm{H}$ NMR $\left(300 \mathrm{MHz}\right.$, DMSO- $\left.d_{6}\right): \delta 8.92(\mathrm{~d}, J=4.8 \mathrm{~Hz}, 1 \mathrm{H}), 8.78(\mathrm{~d}, J=$ $7.8 \mathrm{~Hz}, 1 \mathrm{H}), 8.63(\mathrm{~s}, 1 \mathrm{H}), 8.41-8.33(\mathrm{~m}, 6 \mathrm{H}), 7.92(\mathrm{t}, J=6.6 \mathrm{~Hz}$, $2 \mathrm{H}), 7.87(\mathrm{~d}, J=8.4 \mathrm{~Hz}, 2 \mathrm{H}), 7.54-7.42(\mathrm{~m}, 5 \mathrm{H}), 7.13(\mathrm{t}, J=$ $8.4 \mathrm{~Hz}, 2 \mathrm{H}, A r), 1.44\left(\mathrm{~s}, 18 \mathrm{H},-\mathrm{CH}_{3}\right)$. Elemental analysis calcd (\%) for $\mathrm{C}_{42} \mathrm{H}_{38} \mathrm{ClN}_{3} \mathrm{Pt}$ : C, 61.87; H, 4.70; N, 5.15; found: C, 62.03; H, $4.83 ; \mathrm{N}, 4.98$.

\section{Synthesis of 2}

A mixture of $1(0.24 \mathrm{~g}, 0.3 \mathrm{mmol}), \mathrm{C}_{6} \mathrm{H}_{5} \mathrm{C} \equiv \mathrm{CH}(0.10 \mathrm{~g}, 1.0$ $\mathrm{mmol}), \mathrm{Et}_{3} \mathrm{~N}(5 \mathrm{~mL})$ and $\mathrm{CuI}(5.0 \mathrm{mg}, 0.03 \mathrm{mmol})$ in degassed $\mathrm{CH}_{2} \mathrm{Cl}_{2}(50 \mathrm{~mL})$ was stirred for $24 \mathrm{~h}$ under an argon atmosphere at room temperature in the absence of light. The reaction mixture was then evaporated to dryness under reduced pressure. The crude product was purified by flash chromatography (neutral $\mathrm{Al}_{2} \mathrm{O}_{3}, \mathrm{CH}_{2} \mathrm{Cl}_{2}$ as eluent) and recrystallized from $\mathrm{CH}_{2} \mathrm{Cl}_{2} / \mathrm{MeOH}$ solution to form the desired product as a red crystal in a yield of $84 \% .{ }^{1} \mathrm{H}$ NMR (400 MHz, DMSO- $\left.d_{6}\right): \delta 9.09$ $(\mathrm{d}, J=4.4 \mathrm{~Hz}, 1 \mathrm{H}), 8.80(\mathrm{~d}, J=8.0 \mathrm{~Hz}, 1 \mathrm{H}), 8.71(\mathrm{~s}, 1 \mathrm{H}), 8.46(\mathrm{~s}$, $1 \mathrm{H}), 8.42-8.38(\mathrm{~m}, 3 \mathrm{H}), 8.35(\mathrm{~s}, 2 \mathrm{H}), 7.92-7.87(\mathrm{~m}, 4 \mathrm{H}), 7.78(\mathrm{~d}, J$ $=7.6 \mathrm{~Hz}, 1 \mathrm{H}), 7.53(\mathrm{~d}, J=8.8 \mathrm{~Hz}, 2 \mathrm{H}), 7.45(\mathrm{~d}, J=8.4 \mathrm{~Hz}, 2 \mathrm{H})$, $7.40(\mathrm{~d}, J=7.2 \mathrm{~Hz}, 2 \mathrm{H}), 7.30(\mathrm{t}, J=7.8 \mathrm{~Hz}, 2 \mathrm{H}), 7.19-7.09(\mathrm{~m}, 3 \mathrm{H}$, $\mathrm{Ar}$ ), $1.44\left(\mathrm{~s}, 18 \mathrm{H},-\mathrm{CH}_{3}\right)$. Elemental analysis calcd (\%) for $\mathrm{C}_{50} \mathrm{H}_{43} \mathrm{~N}_{3} \mathrm{Pt}$ : C, 68.17; H, 4.92; N, 4.77; found: C, 68.45; $\mathrm{H}$, $5.10 ; \mathrm{N}, 4.62$.

\section{Synthesis of 3}

To a stirred solution of $1(0.14 \mathrm{~g}, 0.17 \mathrm{mmol})$ and $4^{\prime}$-(4-ethynylphenyl)-2, $2^{\prime}: 6^{\prime}, 2^{\prime \prime}$-terpyridine $(0.07 \mathrm{~g}, 0.18 \mathrm{mmol})$ in degassed $\mathrm{CH}_{2} \mathrm{Cl}_{2}(20 \mathrm{~mL})$, $\mathrm{CuI}(5.4 \mathrm{mg}, 0.03 \mathrm{mmol})$ and $\mathrm{Et}_{3} \mathrm{~N}(4 \mathrm{~mL})$ were successively added. The mixture was stirred for $24 \mathrm{~h}$ under an argon atmosphere at room temperature in the absence of light and then evaporated to dryness under reduced pressure. The crude product was purified by flash chromatography (neutral 
$\mathrm{Al}_{2} \mathrm{O}_{3}, \mathrm{CH}_{2} \mathrm{Cl}_{2}$ as eluent) and recrystallized from $\mathrm{CH}_{2} \mathrm{Cl}_{2} / \mathrm{MeOH}$ solution to form the desired product as a red crystal in a yield of $89 \% .{ }^{1} \mathrm{H}$ NMR (400 MHz, DMSO- $\left.d_{6}\right): \delta 9.10(\mathrm{~d}, J=4.8 \mathrm{~Hz}, 1 \mathrm{H})$, $8.80(\mathrm{~d}, J=4.4 \mathrm{~Hz}, 3 \mathrm{H}), 8.75(\mathrm{~s}, 2 \mathrm{H}), 8.70(\mathrm{~d}, J=8.0 \mathrm{~Hz}, 3 \mathrm{H})$, 8.46-8.38 (m, 4H), 8.35 (s, 2H), 8.06 (t, $J=8.4 \mathrm{~Hz}, 2 \mathrm{H}), 7.93-7.85$ $(\mathrm{m}, 6 \mathrm{H}), 7.82(\mathrm{~d}, J=7.6 \mathrm{~Hz}, 1 \mathrm{H}), 7.60-7.52(\mathrm{~m}, 6 \mathrm{H}), 7.45(\mathrm{~d}, J=$ $8.8 \mathrm{~Hz}, 2 \mathrm{H}), 7.19$ (t, $J=6.8 \mathrm{~Hz}, 1 \mathrm{H}), 7.13(\mathrm{t}, J=7.4 \mathrm{~Hz}, 1 \mathrm{H}, A r)$, $1.43\left(\mathrm{~s}, 18 \mathrm{H},-\mathrm{CH}_{3}\right)$. Elemental analysis calcd (\%) for $\mathrm{C}_{65} \mathrm{H}_{52} \mathrm{~N}_{6}$ Pt: $\mathrm{C}$, 70.19; H, 4.71; N, 7.56; found: C, 70.44; H, 4.86; N, 7.38. Matrix-assisted laser desorption/ionization timeof-flight mass spectrometry (MALDI-TOF MS): $\mathrm{m} / \mathrm{z}=1112.4$ ([M], $\mathrm{C}_{65} \mathrm{H}_{52} \mathrm{~N}_{6}$ Pt requires 1112.39).

\section{General procedure of consecutive titrations}

The titrand solutions of $3(100 \mathrm{~mL})$ were freshly prepared in $\mathrm{CH}_{2} \mathrm{Cl}_{2}$ before the consecutive titration experiment. Absorption and emission spectra were recorded simultaneously after each addition $(10 \mu \mathrm{L})$ of the corresponding titrant solution. Each titration step was stopped after no more changes were observed in the absorption and emission properties. The selectivity of 3 toward different metal cations was monitored by the parallel PL experiment under the same instrument condition, in which 0.5 equiv. of the metal ions was added in each titrand solution containing $1.5 \times 10^{-5} \mathrm{~mol} \mathrm{dm}^{-3} 3$.

\section{Physical measurements and instrumentation}

${ }^{1} \mathrm{H}$ and ${ }^{13} \mathrm{C}\left\{{ }^{1} \mathrm{H}\right\}$ NMR spectra were recorded on Bruker AV 300 and 400 spectrometers and referenced with respect to TMS internal standard. Elemental analyses were carried out using a Bio-Rad Co's elemental analytical instrument. MALDI-TOF MS analyses were performed on a Bruker Autoflex III with a negative reflector mode. UV-vis absorption spectra were obtained using the Perkin-Elmer Lambda 650s ultraviolet-visible spectrophotometer. Steady-state PL spectra were performed on the PerkinElmer LS50B spectrometer. Emission lifetimes and PL quantum yields were determined on the FLS-980 fluorescence spectrometer (Edinburgh Instruments Ltd.) with a microflash lamp as the excitation source. CV spectra were conducted on the CHI660A electrochemical workstation in $\mathrm{CH}_{2} \mathrm{Cl}_{2}$ solutions with a threeelectrode electrochemical cell using Pt electrode, SCE and Pt wire as the working, reference and counter electrodes, respectively. ${ }^{n} \mathrm{Bu}_{4} \mathrm{NClO}_{4}\left(0.1 \mathrm{~mol} \mathrm{~L}{ }^{-1}\right)$ was used as the supporting electrolyte and the scan rate was $50 \mathrm{mV} \mathrm{s}^{-1}$.

\section{X-ray crystallography}

Diffraction data were collected on the Bruker SMART APEX II CCD diffractometer equipped with graphite-monochromated Mo- $\mathrm{K}_{\alpha}$ radiation $(\lambda=0.71073 \AA$ ) at $296(2) \mathrm{K}$ using the $\Phi-\omega$ scan mode. The intensity data were corrected by $L_{\mathrm{p}}$ factors and empirical absorption. The structure was solved by direct methods and subsequent successive difference Fourier maps, and refined by full-matrix least-squares techniques on $F^{2}$. All of the non-hydrogen atoms were refined anisotropically. The organic hydrogen atoms were generated geometrically. All calculations were carried out with SHELXTL-97 program. ${ }^{30}$

\section{Determination of the association constant $\left(K_{\mathrm{a}}\right)$}

The binding constants of 3 toward $\mathrm{Fe}^{2+}$ and $\mathrm{Zn}^{2+}$ from the absorption titration data were calculated using the linear Benesi-Hildebrand equation..$^{31-33}$ Moreover, the binding constants of 3 toward $\mathrm{Fe}^{2+}$ and $\mathrm{Zn}^{2+}$ were evaluated from their fluorescence titration data using the Stern-Volmer expression ${ }^{34,35}$ and the linear Benesi-Hildebrand equation, respectively.

\section{Determination of the limit of detection (LOD)}

The limits of detection of 3 for $\mathrm{Fe}^{2+}$ and $\mathrm{Zn}^{2+}$ ions were calculated using the following equation: ${ }^{32}$

$$
\mathrm{LOD}=3 \sigma / S
$$

where $\sigma$ is the standard deviation of the observed absorption and emission data, and $S$ is the slope of the calibration curve.

\section{Results and discussion}

\section{Synthesis and characterization}

The synthesis of ligand HL and complexes 1-3 explored in this work is shown in Scheme 1. Furthermore, 4 -( $p$-bromophenyl)-6phenyl-2,2'-bipyridine was obtained using Kröhnke's method, and $\quad 4-\{p$-[9-(3,6-di-tert-butyl)carbazolyl $]\}$-phenyl-6-phenyl-2,2'bipyridine (HL) was synthesized by the high-temperature Ullmann condensation between 3,6-di-tert-butylcarbazole and 4- $(p$ bromophenyl)-6-phenyl-2,2'-bipyridine, followed by chromatographic purification. The cyclometalated $\mathrm{Pt}(\mathrm{II})$ chloride 1 was synthesized by refluxing $\mathrm{HL}$ and $\mathrm{K}_{2} \mathrm{PtCl}_{4}$ in glacial acetic acid for $12 \mathrm{~h}$. Finally, reaction of 1 with phenylacetylene and $4^{\prime}-(4-$ ethynylphenyl)-2,2' $: 6^{\prime}, 2^{\prime \prime}$-terpyridine by Sonogashira's method and then purification by flash chromatography and recrystallization resulted in complexes $\mathbf{2}$ and $\mathbf{3}$ as red crystals in good yields, respectively. Both of them have good solubility in $\mathrm{CH}_{2} \mathrm{Cl}_{2}$ and were characterized by ${ }^{1} \mathrm{H}$ NMR, elemental analysis, and/or MALDI-TOF MS. In addition, their structures were revealed by X-ray crystallography.

\section{Crystal structures}

The single crystals of complexes 2 and 3 (CCDC: 991876 and 991877) were grown by slowly evaporating the solvent from their concentrated $\mathrm{CH}_{2} \mathrm{Cl}_{2} / \mathrm{MeOH}$ solutions, and the crystal data and crystal structure parameters are listed in Table S1. $\dagger$ Their perspective views are shown in Fig. 1 and 2. The coordination geometry of the Pt atom is a distorted square planar configuration with the $\mathrm{C}(1)-\mathrm{Pt}(1)-\mathrm{N}(2)$ and $\mathrm{N}(1)-\mathrm{Pt}(1)-\mathrm{C}(35)$ angles of 160.4(18) and $175.8(18)^{\circ}$ for 2 and 160.5(2) and $178.1(2)^{\circ}$ for 3. The bond distances of $\mathrm{Pt}(1)-\mathrm{C}(1), \mathrm{Pt}(1)-\mathrm{N}(1)$ and $\mathrm{Pt}(1)-\mathrm{N}(2)$ are 2.016(5), 1.991(4) and 2.111(4) A for 2 and 1.993(6), 1.981(5) and 2.096(5) A for 3, respectively, which are comparable to those of previously reported analogs. ${ }^{36-39}$ The $\mathrm{C}(1)-\mathrm{C}(6)-\mathrm{C}(7)-\mathrm{N}(1)$ and $\mathrm{N}(1)-\mathrm{C}(11)-\mathrm{C}(12)-\mathrm{N}(2)$ torsion angles of 1.91 and $1.60^{\circ}$ for 2 and 4.34 and $7.23^{\circ}$ for 3 suggest that the configuration of $\left(\mathrm{C}^{\wedge} \mathrm{N}^{\wedge} \mathrm{N}\right)$ ligand is nearly planar. The dihedral angles between the phenyl ring at 4-position of the $\left(\mathrm{C}^{\wedge} \mathrm{N}^{\wedge} \mathrm{N}\right)$ ligand and the plane of the $\left[\left(\mathrm{C}^{\wedge} \mathrm{N}^{\wedge} \mathrm{N}\right) \mathrm{Pt}\right]$ moiety are $32.00^{\circ}$ for 2 and $34.11^{\circ}$ for 3 . In complex 


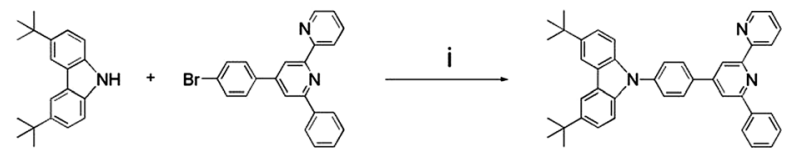

HL

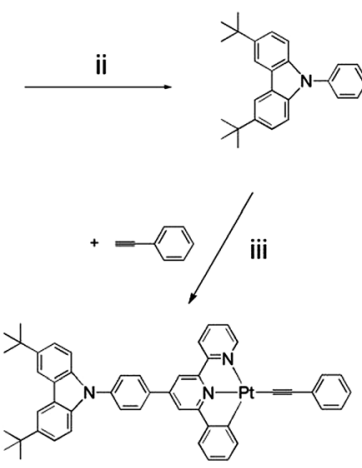

$\left[(\mathrm{L}) \mathrm{Pt}\left(\mathrm{C}=\mathrm{C}-\mathrm{C}_{6} \mathrm{H}_{5}\right)\right](2)$

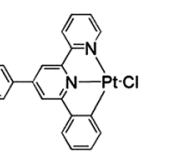

[(L)PtCl] (1)
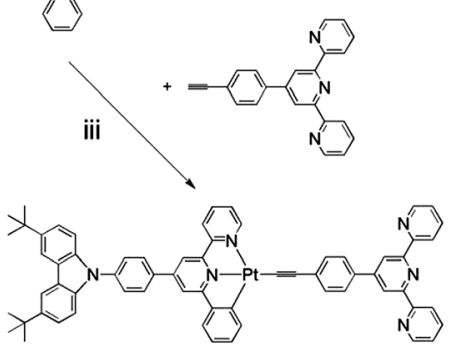

$\left[(\mathrm{L}) \mathrm{Pt}\left(\mathrm{C}=\mathrm{C}-\mathrm{C}_{6} \mathrm{H}_{4}-\mathrm{TPY}\right)\right](3)$ (i) Cul/anhydrous $\mathrm{K}_{2} \mathrm{CO}_{3} / 18$-crown- $6,185^{\circ} \mathrm{C}, 24 \mathrm{~h}$; (ii) $\mathrm{HAc}$, reflux, $12 \mathrm{~h}$; (iii) $\mathrm{Cul} / \mathrm{Et}_{3} \mathrm{~N} / \mathrm{CH}_{2} \mathrm{Cl}_{2}$, absence of light, r.t. stirred $24 \mathrm{~h}$.

Scheme 1 Synthetic route of HL, 1, 2, and 3.

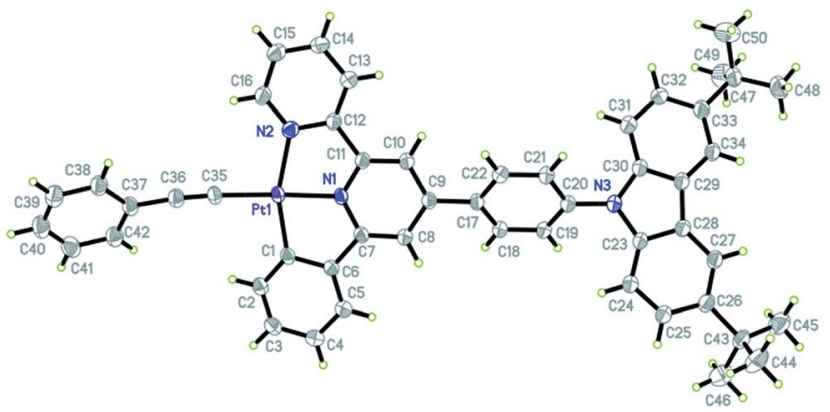

Fig. 1 Perspective view of the single crystal structure of 2 with $30 \%$ thermal ellipsoids (hydrogen atoms have been omitted for clarity).

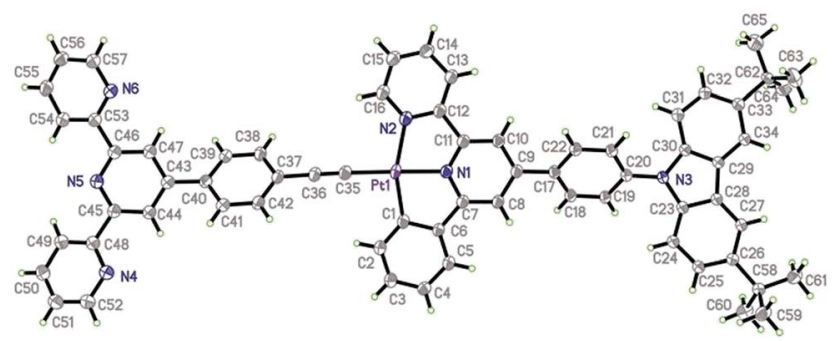

Fig. 2 Perspective view of the single crystal structure of 3 with 30\% thermal ellipsoids (hydrogen atoms have been omitted for clarity).

3, as expected, three pyridine rings of TPY domain exhibit the transoid configuration about interannular $\mathrm{C}-\mathrm{C}$ bonds, and the interplanar angles between two terminal pyridine rings and central pyridine ring are 13.79 and $18.05^{\circ}$, respectively. The terminal TPY and CBZ planes are basically coplanar to the central $\left[\left(\mathrm{C}^{\wedge} \mathrm{N}^{\wedge} \mathrm{N}\right) \mathrm{Pt}\right]$ unit, as evidenced by the dihedral angles of $10.27^{\circ}$ and $9.88^{\circ}$ between them, respectively, indicating its efficient $\pi$-conjugation molecule structure.

Instead of forming a continuous chain linked by the Pt-Pt interaction as in $\left[\left(\mathrm{C}^{\wedge} \mathrm{N}^{\wedge} \mathrm{N}\right) \mathrm{PtCl}\right],{ }^{37,38}$ the crystal lattice of 2 is packed by one type of alternating arranged dimeric units along the $c$ axis (Fig. 3), in which two molecules are stacked in parallel with a Pt-Pt distance of $9.149 \AA$ A. However, complex 3 shows another type of continuously stacked dimers in a head-to-tail fashion along the $a$ axis (Fig. 4). The Pt-Pt distance of $4.725 \AA$ also suggests no metal-metal interaction, but the vertical distance of $3.489 \AA$ A between the neighboring $\left[\left(\mathrm{C}^{\wedge} \mathrm{N}^{\wedge} \mathrm{N}\right) \mathrm{Pt}\right]$ planes indicates that they are likely to be held together by the weak $\pi-\pi$ interaction.

\section{Photophysical properties}

The UV-vis absorption spectra of complex 1-3 in $\mathrm{CH}_{2} \mathrm{Cl}_{2}$ solution exhibit intense bands at 250-400 $\mathrm{nm}$ and less intense bands at 400-550 $\mathrm{nm}$ (Table 1 and Fig. 5). With reference to previous spectroscopic work on phenylbipyridyl platinum(II) complexes, ${ }^{39}$ the high-energy intense absorption bands are clearly assigned to the singlet $\pi \rightarrow \pi^{*}$ intraligand (IL) transitions of phenylbipyridine $\left(\mathrm{C}^{\wedge} \mathrm{N}^{\wedge} \mathrm{N}\right)$ and alkynyl $(\mathrm{C} \equiv \mathrm{C}-\mathrm{Ar})$ ligands, while the low-energy bands are attributed to the well-known spin-allowed singlet $\mathrm{d} \pi(\mathrm{Pt}) \rightarrow \pi^{*}\left(\mathrm{C}^{\wedge} \mathrm{N}^{\wedge} \mathrm{N}\right)$ metal-toligand charge transfer (MLCT) mixing with the $\pi(\mathrm{Cl}$ or $\mathrm{C} \equiv \mathrm{C}-\mathrm{Ar})$ $\rightarrow \pi^{*}\left(\mathrm{C}^{\wedge} \mathrm{N}^{\wedge} \mathrm{N}\right)$ ligand-to-ligand charge transfer (LLCT) transitions. The low-energy absorption bands obey Beer's law in the range of $10^{-6}$ to $10^{-4} \mathrm{~mol} \mathrm{dm}{ }^{-3}$, suggesting no dimerization or oligomerization of these complexes within this concentration range.

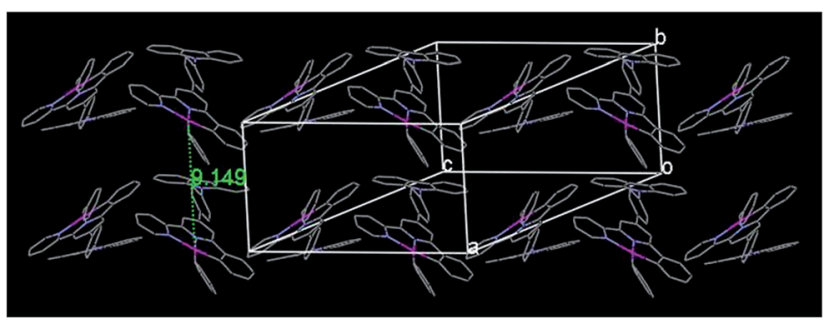

Fig. 3 Crystal packing diagram of 2 (hydrogen atoms and tert-butyl groups have been omitted for clarity).

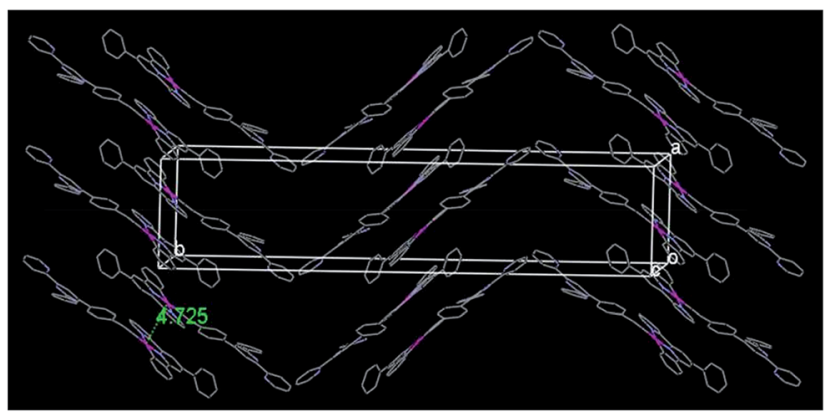

Fig. 4 Crystal packing diagram of 3 (hydrogen atoms and 3,6-di-tertbutylcarbazole units have been omitted for clarity). 
Table 1 Photophysical properties of compounds $1-3^{a}$

\begin{tabular}{|c|c|c|c|c|c|c|}
\hline Compound & $\lambda_{\max , \mathrm{abs}}(\mathrm{nm})\left(\varepsilon \times 10^{4} \mathrm{dm}^{3} \mathrm{~mol}^{-1} \mathrm{~cm}^{-1}\right)$ & $\lambda_{\max , \mathrm{em}}^{b}(\mathrm{~nm})$ & $\Phi_{\mathrm{em}}^{b, c}$ & $\tau_{\mathrm{em}}^{b, c}(\mu \mathrm{s})$ & $k_{\mathrm{nr}}^{d}\left(\times 10^{5}\right)\left(\mathrm{s}^{-1}\right)$ & $k_{\mathrm{r}}^{e}\left(\times 10^{3}\right)\left(\mathrm{s}^{-1}\right)$ \\
\hline 1 & 432 (1.06), 414 (sh, 1.12), 376 (1.71), 336 (2.29), 290 (5.71) & $566,598(\mathrm{sh})$ & 0.019 & 5.10 & 1.92 & 3.73 \\
\hline 2 & 438 (1.34), 376 (2.20), 338 (2.84), 288 (8.80) & 600 & 0.026 & 5.24 & 1.86 & 4.96 \\
\hline $3+\mathrm{Fe}^{2+}(2: 1)^{f}$ & 580 (1.98), 440 (2.58), 366 (sh, 2.97), 326 (5.06), 290 (8.03) & 568 & 0.0065 & 5.32 & 1.87 & 1.22 \\
\hline $3+\mathrm{Zn}^{2+}(2: 1)^{f}$ & 448 (3.20), 382 (sh, 2.53), 332 (4.16), 290 (8.42) & 582 & 0.050 & 5.42 & 1.75 & 9.23 \\
\hline
\end{tabular}

${ }^{a}$ Measured in an air-saturated $\mathrm{CH}_{2} \mathrm{Cl}_{2}$ solution at room temperature. ${ }^{b}$ Excited wavelength is $450 \mathrm{~nm} .{ }^{c}$ PL quantum yields and lifetime. ${ }^{d} k_{\mathrm{nr}}=(1-$ $\Phi) / \tau$. ${ }^{e} k_{\mathrm{r}}=\Phi / \tau .{ }^{f}$ Measured after addition of 0.5 equiv. metal ion into an air-saturated $3 \mathrm{CH}_{2} \mathrm{Cl}_{2}$ solution at room temperature.

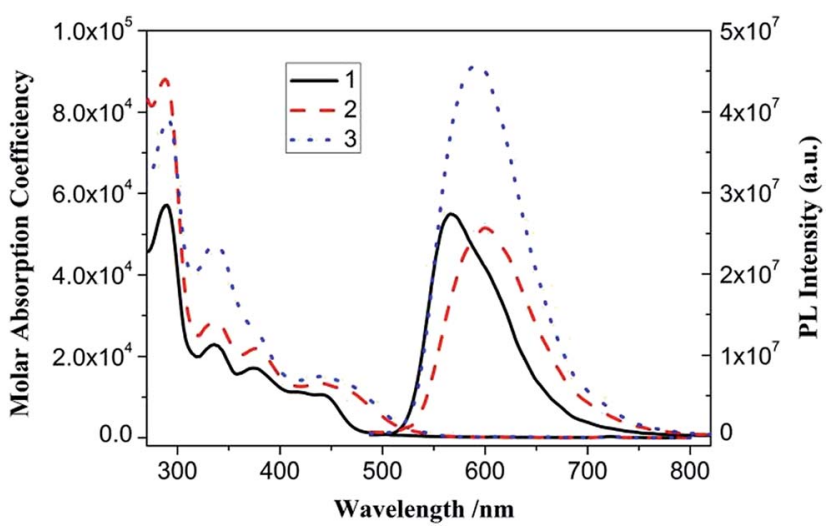

Fig. 5 UV-vis absorption and PL emission spectra of 1, 2 and 3 in $\mathrm{CH}_{2} \mathrm{Cl}_{2}$ solution.

With an excitation at $450 \mathrm{~nm}$, which is into their MLCT absorption bands, 1, 2 and 3 in $\mathrm{CH}_{2} \mathrm{Cl}_{2}$ solution emit reddishorange luminescence (Table 1 and Fig. 5). For each of them, the time-resolved PL intensity decay is complex and is most adequately modeled using a sum of two single exponential functions (Fig. S1 $\dagger$ ). The average lifetimes $\left[\tau=\left(\alpha_{1} \tau_{1}{ }^{2}+\alpha_{2} \tau_{2}{ }^{2}\right) /\right.$ $\left.\left(\alpha_{1} \tau_{1}+\alpha_{2} \tau_{2}\right)\right]$, radiation $\left(k_{\mathrm{r}}\right)$ and non-radiation $\left(k_{\mathrm{nr}}\right)$ rate constants are calculated as listed in Table 1 . The comparably long emission lifetimes ( $\tau$ in $\mu$ s scale), large Stoke's shifts, and $k_{\mathrm{r}}$ and $k_{\mathrm{nr}}$ values suggest that their emissions originate from the spin-forbidden triplet excited states. Complex 2 has longer emission wavelength and lifetime as well as larger quantum yield than 1, resulting from incorporation of the strong-field acetylide ligand to extend its $\pi$-conjugated system and destabilize the non-radiative ligand-field transitions. ${ }^{39,40}$ With further introduction of the electron-withdrawing TPY unit, complex 3 shows a slightly blue-shifted $\left(\Delta \lambda_{\text {max }, \mathrm{em}}=4 \mathrm{~nm}\right)$ and apparently enhanced emission compared with 2, reflecting its lower HOMO level and stronger molecular rigidity. Despite the presence of the dynamical quenching effect of dissolved oxygen, complex 3 still possesses strong emission with comparative quantum yield in air-saturated $\mathrm{CH}_{2} \mathrm{Cl}_{2}$ solution at room temperature, which facilitates the consecutive titration and metal ion sensing studies mentioned later in this study.

In addition, selective optical-stimulation experiment was conducted to study the interaction between components of complex 3. When excited at $338 \mathrm{~nm}$, which is into the CBZ absorption band in the UV region, the ${ }^{3}$ MLCT emission clearly increased compared with that of 3 excited at $450 \mathrm{~nm}$ (Fig. $\mathrm{S} 2 \dagger$ ). The enhanced luminescence efficiency $\left(\left[\left(I_{2} / I_{1}\right)-1\right] \times 100(\%)\right)$ is calculated to be $c a .175 \%$, in which $I_{2}$ and $I_{1}$ stand for the integrated area from 480 to $750 \mathrm{~nm}$ in the emission spectra of 3 excited at 338 and $450 \mathrm{~nm}$, respectively.

The electrochemical behaviors of $\mathrm{HL}$ and 1-3 in $\mathrm{CH}_{2} \mathrm{Cl}_{2}$ solution at room temperature were also investigated by cyclic voltammetry (CV), and the data are listed in Table 2 . The cyclic voltammogram of HL shows a quasi-reversible redox wave $(\Delta E=$ $\left.133 \mathrm{mV}, i_{\mathrm{p}, \mathrm{a}} / i_{\mathrm{p}, \mathrm{c}}=1.0\right)$ at $E_{1 / 2}=+0.75 \mathrm{~V}$. As the oxidation potential of the $\left(\mathrm{ph}-\mathrm{C}^{\wedge} \mathrm{N}^{\wedge} \mathrm{N}\right)$ unit is beyond the potential window of the solvent, this wave is assigned to the mono radical cation formation of the CBZ group. For each of complexes 1-3, the cyclic voltammogram exhibits one reversible reduction couple at similar negative potentials, which presumably

Table 2 Electrochemistry data ${ }^{a}$ of the ligand and Pt(॥) complexes

\begin{tabular}{|c|c|c|c|c|c|c|}
\hline \multirow[b]{2}{*}{ Compound } & \multicolumn{2}{|l|}{ Oxidation $^{b}$} & \multirow[b]{2}{*}{ Reduction $E_{1 / 2}(\mathrm{~V})$} & \multirow[b]{2}{*}{$\operatorname{HOMO}^{c}(\mathrm{eV})$} & \multirow[b]{2}{*}{$\operatorname{LUMO}^{c}(\mathrm{eV})$} & \multirow[b]{2}{*}{$E_{\mathrm{g}}{ }^{c}(\mathrm{eV})$} \\
\hline & Ligand-based, $E_{1 / 2}(\mathrm{~V})$ & Metal-based, $E_{\mathrm{p}, \mathrm{a}}(\mathrm{V})$ & & & & \\
\hline 1 & +0.76 & $+0.40(\mathrm{sh})$ & -1.76 & -4.7 & -2.7 & 2.0 \\
\hline 2 & +0.77 & $+0.50(\mathrm{sh})$ & -1.77 & -4.7 & -2.7 & 2.0 \\
\hline 3 & +0.78 & $+0.60(\mathrm{sh})$ & -1.74 & -4.8 & -2.7 & 2.1 \\
\hline
\end{tabular}

${ }^{a}$ Determined in $\mathrm{CH}_{2} \mathrm{Cl}_{2}$ at room temperature with $0.1 \mathrm{~mol} \mathrm{dm}{ }^{-3}{ }^{n} \mathrm{Bu}_{4} \mathrm{NClO}_{4}$ as a supporting electrolyte, scanning rate: $50 \mathrm{mV} \mathrm{s}{ }^{-1}$. ${ }^{b}$ Values are reported versus $\mathrm{Fc}^{+} / \mathrm{Fc}\left(E_{1 / 2}=+0.46 \mathrm{~V}\right.$ vs. saturated calomel electrode (SCE)). ${ }^{c}$ The highest occupied molecular orbital (HOMO) and the lowest unoccupied molecular orbital (LUMO) levels are calculated from the onset values of their first anodic and cathodic waves according to the equation $E=-\left(E_{\text {onset }}+4.34\right) \mathrm{eV}$, respectively, while the energy gaps $\left(E_{\mathrm{g}}\right)$ are the differences in their HOMO and LUMO levels. 
corresponds to the metal-perturbed one-electron reduction of the $\left(\mathrm{C}^{\wedge} \mathrm{N}^{\wedge} \mathrm{N}\right)$ ligand. In addition, the irreversible $\mathrm{Pt}(\mathrm{II})$-based oxidation wave is shown as a shoulder peak at lower anodic potential than that of the CBZ moiety. ${ }^{41}$ The HOMO and LUMO levels of 1-3 were also estimated from their electrochemical data, ${ }^{42}$ which reveal that the HOMOs are basically Pt(II) acetylide based and the LUMOs predominantly correspond to the $\pi^{*}$ orbitals of cyclometalated ligands..$^{29,40,43-45}$ When the electronwithdrawing TPY group is attached to the phenylacetylide ligand of 2 at para-position, complex 3 possesses a clearly anodic-shifted $\mathrm{Pt}(\mathrm{II})$ oxidation peak $\left(\Delta E_{\mathrm{p}, \mathrm{a}}=0.10 \mathrm{~V}\right)$ and a slightly positive-shifted reduction potential of the $\left(\mathrm{C}^{\wedge} \mathrm{N}^{\wedge} \mathrm{N}\right)$ ligand $\left(\Delta E_{1 / 2}=0.03 \mathrm{~V}\right)$, suggesting that introduction of TPY mainly stabilizes its HOMO energy level $\left(\Delta E_{g}=0.1 \mathrm{eV}\right)$. These results are consistent with the above-mentioned spectroscopic studies and theoretical calculations on the frontier molecular orbitals of phosphorescent cyclometalated Pt(II) acetylide.

\section{Titration of 3 with $\mathrm{Fe}^{2+}$}

As shown in Fig. 6a, besides the presence of the $\mathrm{d} \pi(\mathrm{Pt}) \rightarrow$ $\pi^{*}\left(\mathrm{C}^{\wedge} \mathrm{N}^{\wedge} \mathrm{N}\right){ }^{1}$ MLCT absorption band $\left(\lambda_{\max }=442 \mathrm{~nm}\right)$ of 3 , a new spin-allowed singlet $\mathrm{d} \pi(\mathrm{Fe}) \rightarrow \pi^{*}(\mathrm{TPY})$ metal-to-ligand charge transfer ( ${ }^{1}$ MLCT) transition ${ }^{46,47}$ appeared at $\lambda_{\max }=580 \mathrm{~nm}$ upon addition of $\mathrm{Fe}^{2+}$ (Table 1 and Fig. S3†). Both of them are gradually increased, and they finally reach their maxima when titrated with 0.5 molar amount of $\mathrm{Fe}^{2+}$ (Fig. 6a, inset). These results suggest that the added iron ions bond to the free TPY receptor of 3 with $1: 2$ stoichiometry to form the heterotrinuclear complex (Pt-Fe-Pt) containing the $\left[\mathrm{Fe}(\mathrm{TPY})_{2}\right]^{2+}$ core. A perfect linear relationship $(R=0.99983)$ is established from the absorption titration data for the plot, and absorbance was measured at $580 \mathrm{~nm}$ as a function of $\left[\mathrm{Fe}^{2+}\right]$ (from 0 to $4.50 \times$ $10^{-6} \mathrm{~mol} \mathrm{dm}^{-3}$ ) (Fig. S4 $\dagger$ ). The colorimetric LOD is $8.21 \times$ $10^{-8} \mathrm{~mol} \mathrm{dm}^{-3}$, which is comparable to that of the ruthenium(II) complex-based chemosensor ${ }^{48}$ and much lower than that of benzimidazole-based chemosensor. ${ }^{49}$ By plotting the measured $\left[1 /\left(A-A_{0}\right)\right]$ at $580 \mathrm{~nm}$ as a function of $1 /\left[\mathrm{Fe}^{2+}\right]$ based on the well-known Benesi-Hildebrand expression (Fig. S5†), a good linear relationship $(R=0.99958)$ is obtained, and the association constant of 3 with $\mathrm{Fe}^{2+}, K_{\mathrm{a}}=5.06 \times 10^{4} \mathrm{~mol}^{-1} \mathrm{dm}^{3}$, is calculated from the slope and intercept of this linear plot. Owing to its lower energy excited state of the as-formed $\left[\mathrm{Fe}(\mathrm{TPY})_{2}\right]^{2+}$ core in the Pt-Fe-Pt heterotrinuclear complex, ${ }^{9}$ the photoinduced energy/electron transfer (PET) process from the peripheral cyclometalated Pt(II) complex units to the central Fe-TPY complex quenches the MLCT emission of 3 with a much smaller quantum yield of 0.0065 (Fig. 6b). A good linear relationship $(R=-0.99861)$ between the PL intensity and $\left[\mathrm{Fe}^{2+}\right]$ (from 0 to $4.50 \times 10^{-6} \mathrm{~mol} \mathrm{dm}^{-3}$ ) is also obtained from the quenching titration data (Fig. S6 $\dagger$ ), and the LOD is $2.38 \times$ $10^{-7} \mathrm{~mol} \mathrm{dm}^{-3}$, which is an order of magnitude lower than that of the benzoimidazoquinazoline-based fluorescent chemosensor..$^{50}$ In addition, the apparent association constant of 3 with $\mathrm{Fe}^{2+}, K_{\mathrm{a}}=3.14 \times 10^{5} \mathrm{~mol}^{-1} \mathrm{dm}^{3}(R=0.9934)$, is determined from the Stern-Volmer plot (Fig. S7†). The inflection point of the curve measured the PL intensity at $596 \mathrm{~nm}$ as
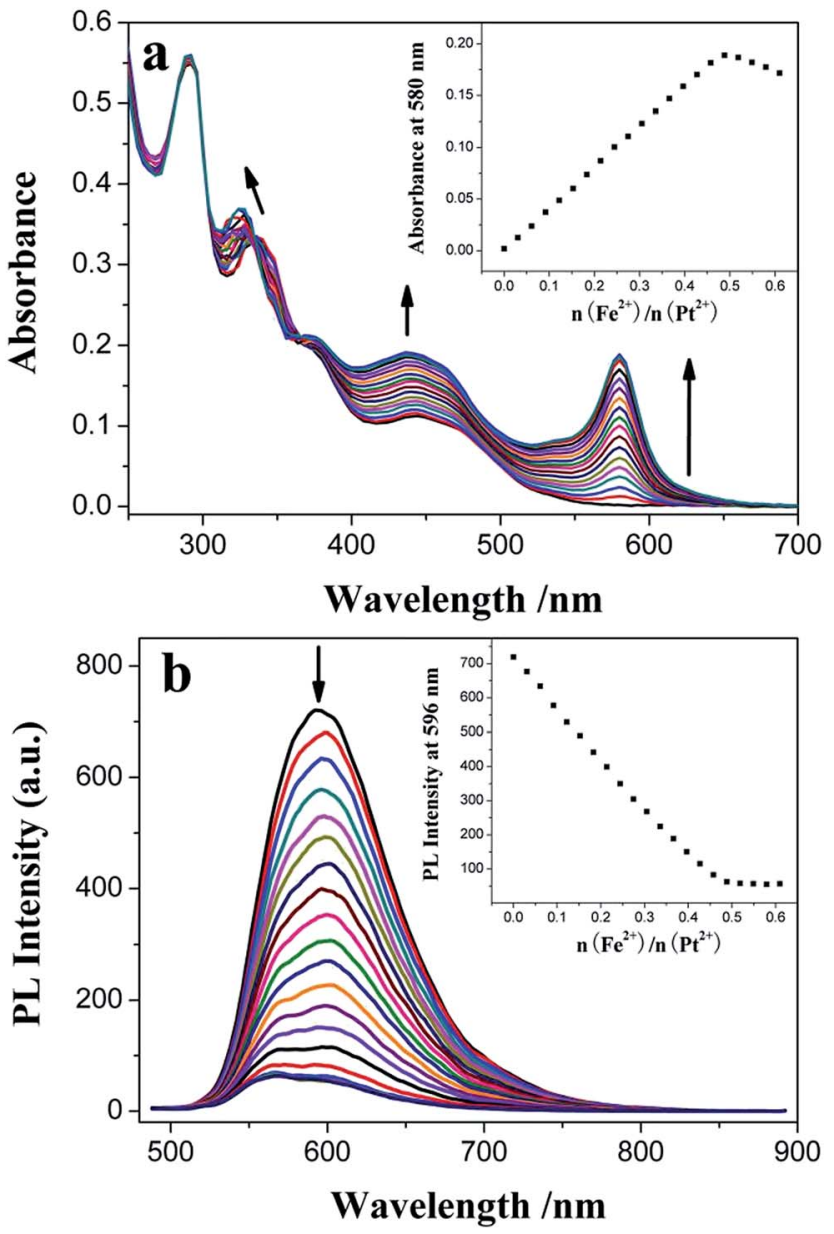

Fig. 6 Influence of consecutive $\mathrm{Fe}^{2+}$ titration on the UV-vis absorption (a) and $\mathrm{PL}$ emission (b) spectra of $1.50 \times 10^{-5} \mathrm{~mol} \mathrm{dm}^{-3} 3$ in $\mathrm{CH}_{2} \mathrm{Cl}_{2}$ solution. The insets show plots of absorbance at $580 \mathrm{~nm}$ and integrated area of the emission wave in the range of $500-800 \mathrm{~nm}$ versus the molar ratio of added $\mathrm{Fe}^{2+}$ and the central $\mathrm{Pt}^{2+}$ ion of 3 , respectively.

a function of the molar ratio of added $\mathrm{Fe}^{2+}$ and the central $\mathrm{Pt}^{2+}$ ion of 3 is also $c a$. 0.5 (Fig. 6b, inset), further confirming the $1: 2$ stoichiometry composition of the Pt-Fe-Pt heterotrinuclear complex. Though the quenching effect is observed during the titration process, the MLCT emission of 3 is not fully quenched upon excessive addition of $\mathrm{Fe}^{2+}$ and the maximum PET efficiency $\left(\left[\left(I_{0}-I_{\min }\right) / I_{0}\right] \times 100(\%)\right)$ is estimated to be $92.4 \%$ (Table 1 and Fig. S8†).

\section{Titration of 3 with $\mathrm{Zn}^{2+}$}

A similar titration experiment was conducted in $\mathrm{CH}_{2} \mathrm{Cl}_{2}$ solution containing $1.50 \times 10^{-5} \mathrm{~mol} \mathrm{dm}{ }^{-3} 3$ using $\mathrm{Zn}^{2+}$ instead of $\mathrm{Fe}^{2+}$, but different absorption and emission changes were observed: (1) the $\mathrm{d} \pi(\mathrm{Pt}) \rightarrow \pi^{*}\left(\mathrm{C}^{\wedge} \mathrm{N}^{\wedge} \mathrm{N}\right){ }^{1}$ MLCT absorption band of 3 is gradually increased with red-shift $\left(\Delta \lambda_{\text {max,abs }}=6 \mathrm{~nm}\right)$ of its wavelength maximum (Fig. 7a). In the range of $0-4.00 \times 10^{-6} \mathrm{~mol} \mathrm{dm}^{-3}$, its intensity is linearly dependent on $\left[\mathrm{Zn}^{2+}\right](R=0.99833)$ (Fig. S9†) and the colorimetric LOD is $2.42 \times 10^{-7} \mathrm{~mol} \mathrm{dm}^{-3}$. The 

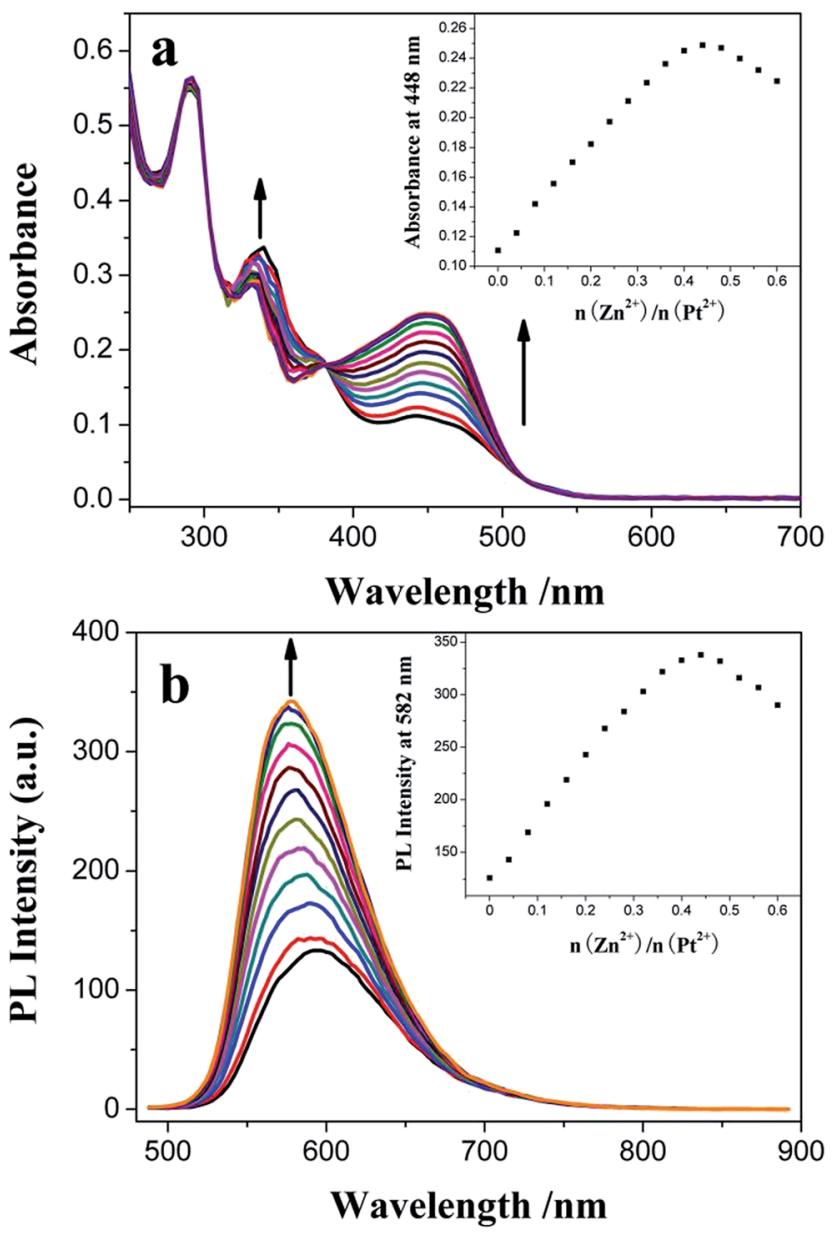

Fig. 7 Influence of consecutive $\mathrm{Zn}^{2+}$ titration on the UV-vis absorption (a) and $\mathrm{PL}$ emission (b) spectra of $1.50 \times 10^{-5} \mathrm{~mol} \mathrm{dm} \mathrm{dm}^{-3} 3 \mathrm{in}$ $\mathrm{CH}_{2} \mathrm{Cl}_{2}$ solution. The insets show plots of absorbance at $448 \mathrm{~nm}$ and integrated area of the emission wave in the range of $500-800 \mathrm{~nm}$ versus the molar ratio of added $\mathrm{Zn}^{2+}$ and the central $\mathrm{Pt}^{2+}$ ion of 3 , respectively.

association constant of 3 with $\mathrm{Zn}^{2+}$ is calculated to be $K_{\mathrm{a}}=5.16 \times$ $10^{4} \mathrm{~mol}^{-1} \mathrm{dm}^{3}(R=0.99967)$ from its Benesi-Hildebrand plot (Fig. S10 $\dagger$ ). (2) And the MLCT emission band of 3 is also gradually increased, but with a clear blue-shift $\left(\Delta \lambda_{\text {max,em }}=14 \mathrm{~nm}\right)$ of its wavelength maximum (Fig. 7b). The linear relationship $(R=$ 0.99632 , from 0 to $\left.4.00 \times 10^{-6} \mathrm{~mol} \mathrm{dm}{ }^{-3}\right)$, the LOD value of $3.61 \times 10^{-7} \mathrm{~mol} \mathrm{dm}^{-3}$ and the association constant of 3 with $\mathrm{Zn}^{2+}$ $\left(K_{\mathrm{a}}=4.50 \times 10^{4} \mathrm{~mol}^{-1} \mathrm{dm}^{3}, R=0.99789\right)$ are also obtained from its PL titration data (Fig. S11 and S12†). The LOD is lower than or comparable to those of organic ${ }^{51-54}$ and transition metal complex fluorophores. ${ }^{29,55,56}$ When the molar ratio of $\mathrm{Zn}^{2+} / \mathrm{Pt}^{2+}$ is near to 0.5 (Fig. 7, inset), the MLCT absorption band at $\lambda_{\max }=448 \mathrm{~nm}$ and the corresponding emission band at $\lambda_{\max }=582 \mathrm{~nm}$ reach their maxima, indicating the formation of the Pt-Zn-Pt heterotrinuclear complex with 1:2 stoichiometry composition. The MLCT absorption sensitivity and emission enhancement effects ${ }^{29}$ (Table 1, Fig. S3 and S8†) strongly suggest that the PET process from the central high energy $\left[\mathrm{Zn}(\mathrm{TPY})_{2}\right]^{2+}$ core to cyclometalated $\mathrm{Pt}(\mathrm{II})$ complex units is present in this multi-component complex with a maximum efficiency $\left(\left[\left(I_{\max }-I_{0}\right) / I_{0}\right] \times 100(\%)\right)$ of $62.7 \%$.

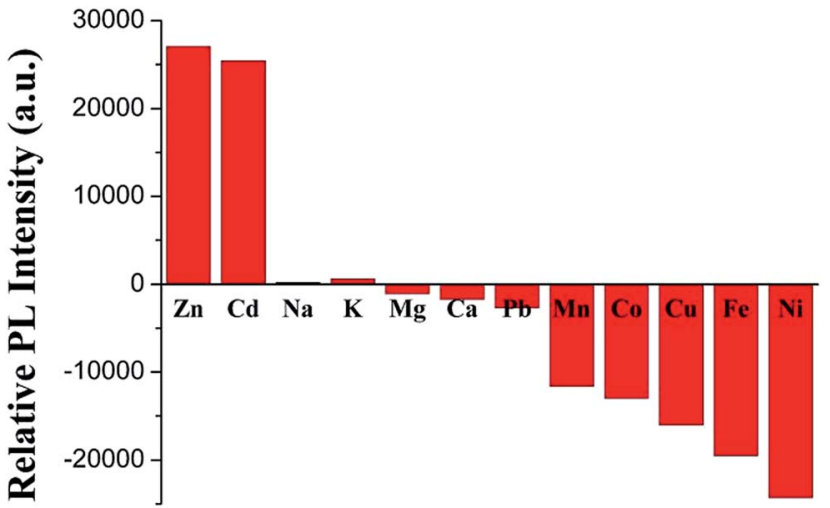

Fig. $8 \mathrm{PL}$ responses of 3 toward various metal ions.

Moreover, introduction of $\mathrm{Zn}^{2+}$, a strong Lewis acid, further stabilizes the Pt(II) acetylide-based HOMO level relative to the "free" TPY complex 3, resulting in the blue-shift of its emission band, which is accordant with its spectroscopic and electrochemical studies.

\section{Selectivity}

The binding behaviors of 3 toward different metal cations (0.5 equiv. of 3) were monitored by PL spectroscopy under the same condition. As expected, in Fig. 8, alkali $\left(\mathrm{Na}^{+}\right.$and $\left.\mathrm{K}^{+}\right)$, alkali-earth $\left(\mathrm{Mg}^{2+}\right.$ and $\left.\mathrm{Ca}^{2+}\right)$ and $\mathrm{Pb}^{2+}$ ions elicit no significant luminescence quenching or enhancing response. Similar to $\mathrm{Fe}^{2+}$, the other common transition metal ions, such as $\mathrm{Mn}^{2+}, \mathrm{Co}^{2+}, \mathrm{Cu}^{2+}$, and $\mathrm{Ni}^{2+}$, also exhibit dramatic luminescence quenching effects. With the same filled $\mathrm{d}^{10}$ electronic configuration, $\mathrm{Cd}^{2+}$ displays a similar luminescence enhancement factor to $\mathrm{Zn}^{2+}$, which is accordant with those of other TPY- and its analog-based chemosensors. $^{28,40,57}$

\section{Conclusions}

In this study, we synthesized a novel cyclometalated Pt(II) acetylide (3) derivative bearing a CBZ donor and a TPY receptor, whose molecular structure is clearly demonstrated by X-ray crystallography. This efficient $\pi$-conjugation system displays an intense ${ }^{1}$ MLCT absorption band $(\varepsilon=1.51 \times$ $10^{4} \mathrm{dm}^{3} \mathrm{~mol}^{-1} \mathrm{~cm}^{-1}$ ) at $\lambda_{\max }=442 \mathrm{~nm}$ and a strong ${ }^{3}$ MLCT phosphorescence emission $(\Phi=0.045)$ at $\lambda_{\max }=596 \mathrm{~nm}$ in airsaturated $\mathrm{CH}_{2} \mathrm{Cl}_{2}$ solution at room temperature. Owing to the presence of the free TPY receptor, complex 3 possesses the expected luminescence responses toward common transition metal cations, e.g. the $\mathrm{Fe}^{2+}$-quenched and $\mathrm{Zn}^{2+}$-enhanced luminescence behaviors. The $3-\mathrm{Fe}^{2+}$ and $3-\mathrm{Zn}^{2+}$ binding constants are correspondingly calculated from their absorption $\left(K_{\mathrm{a}}=5.06 \times 10^{4} \mathrm{~mol}^{-1} \mathrm{dm}^{3}\right.$ for $3-\mathrm{Fe}^{2+}$ and $5.16 \times 10^{4} \mathrm{~mol}^{-1}$ $\mathrm{dm}^{3}$ for $\left.3-\mathrm{Zn}^{2+}\right)$ and emission $\left(3.14 \times 10^{5} \mathrm{~mol}^{-1} \mathrm{dm}^{3}\right.$ for $3-\mathrm{Fe}^{2+}$ and $4.50 \times 10^{4} \mathrm{~mol}^{-1} \mathrm{dm}^{3}$ for $3-\mathrm{Zn}^{2+}$ ) titration data. The formation of the heterotrinuclear (Pt-M-Pt) complex with $1: 2$ stoichiometry is proven by the consecutive titrations, and the intra-molecular energy transfers between the $\left[\mathrm{M}(\mathrm{TPY})_{2}\right]^{2+}$ core 
and the terminal emission Pt(II) complex units are also quantitatively verified with the maximum PET efficiencies of $92.4 \%$ for $3-\mathrm{Fe}^{2+}$ system and $62.7 \%$ for $3-\mathrm{Zn}^{2+}$ system.

\section{Conflicts of interest}

There are no conflicts to declare.

\section{Acknowledgements}

This work was financially supported by the National Natural Science Foundation of China (No: 21571109), the Natural Science Foundation of Henan Province (No: 102300410221), the Natural Science Foundation of Nanyang Normal University (No: ZX2010012) and the Project supported by the Young Core Instructor from the Education Commission of Henan Province.

\section{Notes and references}

1 J. N. Demas and B. A. DeGraff, Coord. Chem. Rev., 2001, 211, 317-351.

2 M. H. Keefe, K. D. Benkstein and J. T. Hupp, Coord. Chem. Rev., 2000, 205, 201-228.

3 M. Formica, V. Fusi, L. Giorgi and M. Micheloni, Coord. Chem. Rev., 2012, 256, 170-192.

4 V. W. Yam, R. P. Tang, K. M. Wong, X. Lu, K. Cheung and N. Zhu, Chem.-Eur. J., 2002, 8, 4066-4076.

5 V. W. Yam, R. P. Tang, K. M. Wong, C. Ko and K. Cheung, Inorg. Chem., 2001, 40, 571-574.

6 P. K. M. Siu, S. Lai, W. Lu, N. Zhu and C. Che, Eur. J. Inorg. Chem., 2003, 2003, 2749-2752.

7 H. Lo, S. Yip, K. M. Wong, N. Zhu and V. W. Yam, Organometallics, 2006, 25, 3537-3540.

8 M. L. Muro, S. Diring, X. Wang, R. Ziessel and F. N. Castellano, Inorg. Chem., 2009, 48, 11533-11542.

9 M. L. Muro, S. Diring, X. Wang, R. Ziessel and F. N. Castellano, Inorg. Chem., 2008, 47, 6796-6803.

10 V. V. Sivchik, E. V. Grachova, A. S. Melnikov, S. N. Smirnov, A. Y. Ivanov, P. Hirva, S. P. Tunik and I. O. Koshevoy, Inorg. Chem., 2016, 55, 3351-3363.

11 M. H. Y. Chan, H. L. Wong and V. W. W. Yam, Inorg. Chem., 2016, 55, 5570-5577.

12 Y. Ai, Y. Li, H. Ma, C. Y. Su and V. W. W. Yam, Inorg. Chem., 2016, 55, 11920-11929.

13 C. J. Lin, Y. H. Liu, S. M. Peng, T. Shinmyozu and J. S. Yang, Inorg. Chem., 2017, 56, 4978-4989.

14 G. Liu, F. Liang, Y. Zhao, H. Hu, J. Fan and L. S. Liao, J. Mater. Chem. C, 2017, 5, 1944-1951.

15 X. Li, J. Hu, Y. Wu, R. Li, D. Xiao, W. Zeng, D. Zhang, Y. Xiang and W. Jin, Dyes Pigm., 2017, 141, 188-194.

16 Y. T. Liu, Y. R. Li, X. Wang and F. Q. Bai, Dyes Pigm., 2017, 142, 55-61.

17 W. Zhang, Y. Luo, Y. Xu, L. Tian, M. Li, R. He and W. Shen, Dalton Trans., 2015, 44, 18130-18137.

18 S. Stoccoro, L. Maidich, T. Ruiu, M. A. Cinellu, G. J. Clarkson and A. Zucca, Dalton Trans., 2015, 44, 18001-18011.
19 X. P. Zhang, F. Q. Liu, J. C. Lai, C. H. Li, A. M. Lia and X. Z. You, New J. Chem., 2016, 40, 2628-2636.

20 J. Li, X. He, Y. Zou, D. Chen, L. Yang, J. Rao, H. Chen, M. C. W. Chan, L. Li, Z. Guo, L. W. Zhang and C. Chen, Metallomics, 2017, 9, 726-733.

21 J. Sanning, L. Stegemann, P. R. Ewen, C. Schwermann, C. G. Daniliuc, D. Zhang, N. Lin, L. Duan, D. Wegner, N. L. Doltsinis and C. A. Strassert, J. Mater. Chem. C, 2016, 4, 2560-2565.

22 W. Yang and J. Zhao, Eur. J. Inorg. Chem., 2016, 2016, 5283-5299.

23 W. Lu, M. C. W. Chan, K. K. Cheung and C. M. Che, Organometallics, 2001, 20, 2477-2486.

24 S. C. F. Kui, S. S. Y. Chui, C. M. Che and N. Zhu, J. Am. Chem. Soc., 2006, 128, 8297-8309.

25 Z. L. Gong and Y. W. Zhong, Inorg. Chem., 2016, 55, 1014310151.

26 K. Li, G. S. M. Tong, Q. Wan, G. Cheng, W. Y. Tong, W. H. Ang, W. L. Kwong and C. M. Che, Chem. Sci., 2016, 7, 1653-1673.

27 Q. Yang, L. Wu, H. Zhang, B. Chen, Z. Wu, L. Zhang and C. Tung, Inorg. Chem., 2004, 43, 5195-5197.

28 P. H. Lanoë, J. L. Fillaut, V. Guerchais, H. Le Bozec and J. A. G. Williams, Eur. J. Inorg. Chem., 2011, 2011, 1255-1259.

29 D. Qiu, M. Li, Q. Zhao, H. Wang and C. Yang, Inorg. Chem., 2015, 54, 7774-7782.

30 G. M. Sheldrick, SHELX-97, Program for Crystal Structure Analysis, University of Göttingen, Göttingen, Germany, 1997.

31 S. Anbu, R. Ravishankaran, M. F. C. Guedes da Silva, A. A. Karande and A. J. L. Pombeiro, Inorg. Chem., 2014, 53, 6655-6664.

32 X. B. Yang, B. X. Yang, J. F. Ge, Y. J. Xu, Q. F. Xu, J. Liang and J. M. Lu, Org. Lett., 2011, 13, 2710-2713.

33 M. Zhu, M. Yuan, X. Liu, J. Xu, J. Lv, C. Huang, H. Liu, Y. Li, S. Wang and D. Zhu, Org. Lett., 2008, 10, 1481-1484.

34 C. Qin, X. Wu, B. Gao, H. Tong and L. Wang, Macromolecules, 2009, 42, 5427-5429.

35 P. Mahato, S. Saha and A. Das, J. Phys. Chem. C, 2012, 116, 17448-17457.

36 S. W. Lai, M. C. W. Chan, K. K. Cheung and C. M. Che, Organometallics, 1999, 18, 3327-3336.

37 S. W. Lai, H. W. Lam, W. Lu, K. K. Cheung and C. M. Che, Organometallics, 2002, 21, 226-234.

38 A. Hofmann, L. Dahlenburg and R. van Eldik, Inorg. Chem., 2003, 42, 6528-6538.

39 W. Lu, B. X. Mi, M. C. W. Chan, Z. Hui, C. M. Che, N. Zhu and S. T. Lee, J. Am. Chem. Soc., 2004, 126, 4958-4971.

40 C. Latouche, P. H. Lanoë, J. A. G. Williams, V. Guerchais, A. Boucekkine and J. L. Fillaut, New J. Chem., 2011, 35, 2196-2202.

41 D. Qiu, X. Bao, Y. Feng, K. Liu, H. Wang, H. Shi, Y. Guo, Q. Huang, J. Zeng, J. Zhou and Z. Xing, Electrochim. Acta, 2012, 60, 339-346.

42 G. Zhou, N. Pschirer, J. C. Schöneboom, F. Eickemeyer, M. Baumgarten and K. Müllen, Chem. Mater., 2008, 20, 1808-1815.

43 P. Shao, Y. Li, A. Azenkeng, M. R. Hoffmann and W. Sun, Inorg. Chem., 2009, 48, 2407-2419. 
44 X. Wang, S. Goeb, Z. Ji and F. N. Castellano, J. Phys. Chem. B, 2010, 114, 14440-14449.

45 G. J. Zhou, X. Z. Wang, W. Y. Wong, X. M. Yu, H. S. Kwok and Z. Lin, J. Organomet. Chem., 2007, 692, 3461-3473.

46 D. Qiu, Y. Cheng and L. Wang, Dalton Trans., 2009, 2009, 3247-3261.

47 X. Bao, Q. Zhao, H. Wang, K. Liu and D. Qiu, Inorg. Chem. Commun., 2013, 38, 88-91.

48 Z. Zheng, Z. Duan, Y. Ma and K. Wang, Inorg. Chem., 2013, 52, 2306-2316.

49 Y. S. Kim, J. J. Lee, S. Y. Lee, T. G. Jo and C. Kim, $R S C A d v$, 2016, 6, 61505-61515.

50 S. Sen, S. Sarkar, B. Chattopadhyay, A. Moirangthem, A. Basu, K. Dhara and P. Chattopadhyay, Analyst, 2012, 137, 3335-3342.
51 R. Azadbakht, M. Koolivand and J. Khanabadi, Anal. Methods, 2017, 9, 4688-4694.

52 S. A. Ingale and F. Seela, J. Org. Chem., 2012, 77, 9352-9356. 53 X. Yang, B. Yang, J. Ge, Y. Xu, Q. Xu, J. Liang and J. Lu, Org. Lett., 2011, 13, 2710-2713.

54 Y. Zhou, Z. Li, S. Zang, Y. Zhu, H. Zhang, H. Hou and T. C. W. Mak, Org. Lett., 2012, 14, 1214-1217.

55 D. Ma, H. He, H. Zhong, S. Lin, D. S. Chan, L. Wang, S. M. Lee, C. Leung and C. Wong, ACS Appl. Mater. Interfaces, 2014, 6, 14008-14015.

56 L. Zhang, L. Xing, B. Chen, Q. Yang, Q. Tong, L. Wu and C. Tung, Dalton Trans., 2013, 42, 4244-4247.

57 W. Goodall and J. A. G. Williams, Chem. Commun., 2001, 2001, 2514-2515. 